\title{
Intravenous Diltiazem or Metoprolol Administration in the Emergency Department for Acute Rate Control of Atrial Fibrillation Patients with Rapid Ventricular Response with Unknown Ejection Fraction
}

\author{
Acil Serviste Ejeksiyon Fraksiyonu Bilinmeyen Hızlı Ventriküler Yanıtlı Atriyal Fibrilasyon \\ Hastalarının Akut Hız Kontrolünde İntravenöz Diltiazem veya Metoprolol Uygulaması
}

\author{
Mehmet Cihat DEMİR \\ (D) 0000-0002-0106-3383 \\ Muharrem DOĞAN ${ }^{2}$ \\ (D) 0000-0003-3954-5713 \\ Esra POLAT ${ }^{3}$ \\ (D) 0000-0002-2330-2816 \\ Güleser AKPINAR ${ }^{1}$ \\ (D) 0000-0001-8559-5098
}

\begin{abstract}
Aim: Atrial fibrillation (AF) is the most widespread persistent cardiac arrhythmia in adults. There is no standard procedure applied in AF patients with rapid ventricular response with unknown ejection fraction (EF) in the emergency department. This study aimed to compare the effectiveness and side effects of diltiazem and metoprolol treatments without knowing the $\mathrm{EF}$ in $\mathrm{AF}$ patients with rapid ventricular response in the emergency department.

Material and Methods: Patients with a ventricular response $\geq 110 / \mathrm{min}$ were selected as having $\mathrm{AF}$ with rapid ventricular response. The patients first received $25 \mathrm{mg}$ intravenous diltiazem as a rate control drug were compared with those first received $5 \mathrm{mg}$ metoprolol. A total of 50 patients whose EF were not registered before the admission date and was measured after being consulted for cardiology following acute rate control in emergency department were included in this study.

Results: For the first drug treatment, diltiazem was given to $56 \%(\mathrm{n}=28)$ of the patients and metoprolol to $44 \%(n=22)$. Moreover, $44 \%(n=22)$ of the patients needed a second drug infusion. The proportion of patients received diltiazem in those with preserved EF was

$(\mathrm{p}=0.157)$.

Conclusion: Diltiazem was found to reduce heart rate earlier than metoprolol. While updating the guidelines for drug selection in acute rate control of AF with rapid ventricular response, rural emergency departments, where EF measurement cannot be achieved, should also be considered.
\end{abstract} ${ }^{1}$ Düzce University Faculty of Medicine significantly higher than those with reduced EF ( $\mathrm{p}=0.032$ ). No statistically significant Department of Emergency Medicine, difference was found between the rates of needing a second administration based on the EF Düzce, Turkey

${ }^{2}$ Sinop Atatürk State Hospital Department of Emergency Medicine, Sinop, Turkey

${ }^{3}$ Fethiye State Hospital Department of Cardiology, Muğla, Turkey

\section{Corresponding Author Sorumlu Yazar \\ Mehmet Cihat DEMIR \\ mdcihat@gmail.com}

Received / Geliş Tarihi : 12.12.2020 Accepted / Kabul Tarihi : 08.02.2021 Available Online /

Çevrimiçi Yayın Tarihi : 16.02.2021
Keywords: Atrial fibrillation; diltiazem; ejection fraction; emergency department; metoprolol; rapid ventricular response.

ÖZ

Amaç: Atriyal fibrilasyon (AF) erişkinlerdeki en yaygın inatçı kardiyak aritmidir. Acil serviste, ejeksiyon fraksiyonu (EF) bilinmeyen hızlı ventrikül yanıtlı AF hastalarında uygulanan standart bir tedavi prosedürü yoktur. Bu çalışmanın amacı acil serviste EF'si bilinmeyen hızlı ventrikül yanıtlı AF hastalarında diltiazem ve metoprolol tedavilerinin etkinliğinin ve yan etkilerinin karşılaştırılmasıdır.

Gereç ve Yöntemler: Ventriküler yanıtı $\geq 110$ /dk olan hastalar, hızlı ventrikül yanıtlı AF olarak kabul edildi. Hız kontrolünde ilk ilaç olarak $25 \mathrm{mg}$ intravenöz diltiazem almış olan hastalar, ilk ilaç olarak $5 \mathrm{mg}$ metoprolol almış olanlar ile karşılaştırıldı. Başvuru tarihinden önce EF değeri kaydedilmemiş olan ve acil serviste akut hız kontrolünü takiben kardiyoloji bölümüne konsülte edildikten sonra ölçülen toplam 50 hasta bu çalışmaya dahil edildi.

Bulgular: İlk ilaç tedavisi olarak hastaların \%56 ( $\mathrm{n}=28)$ 'sına diltiazem ve $\% 44(\mathrm{n}=22)$ 'üne metoprolol verilmişti. İkinci bir ilaç tedavisine ihtiyaç duyan hastaların oranı ise \%44 $(n=22)$ idi. EF korunmuş olanlarda diltiazem alan hastaların oranı, EF azalmış olanlara göre anlamlı derecede daha yüksek idi $(\mathrm{p}=0.032)$. Hastaların $E F$ 'sine göre ikinci bir uygulama ihtiyacı olma oranları arasında istatistiksel olarak anlamlı bir fark bulunmadı $(\mathrm{p}=0.157)$.

Sonuç: Diltiazemin kalp atım hızını metoprolole göre daha erken düşürdüğü görüldü. Hızlı ventrikül yanıtlı AF'nin akut hız kontrolünde ilaç seçimi için kılavuzlar güncellenirken, EF ölçümünün elde edilemediği kırsal acil servisler de göz önünde bulundurulmalıdır.

Anahtar kelimeler: Atriyal fibrilasyon; diltiazem; ejeksiyon fraksiyonu; acil servis; metoprolol; hızlı ventriküler yanit. 


\section{INTRODUCTION}

Atrial fibrillation (AF) is a supraventricular arrhythmia diagnosed with the presence of irregular RR intervals and the absence of regular repetitive $P$ waves for $\geq 30$ seconds or longer with 12-lead electrocardiography (ECG) or single-lead ECG (1).

AF is the most widespread persistent cardiac arrhythmia in adults (2). The incidence of AF in men and women increases with age (3). According to estimates based on the increase in the elderly population, it is expected that there will be 12.1 million AF patients in the United States by 2030. The incidence of symptomatic patients who admitted to the emergency department (ED) due to the increased prevalence of AF patients has also risen (4).

There is still uncertainty in AF treatment management, which is seen as a critical public health issue (5). No significant difference in mortality has been found between rate control and rhythm control in AF (6). The treatment used for rate control in AF changes according to the patient's condition, symptoms, ejection fraction (EF), and hemodynamics (1).

It is not always possible to estimate the EF in the rural ED. There is no standard procedure applied in AF patients with the rapid ventricular response (RVR) without knowing the patient's EF in the ED. Drug selection according to EF is recommended in current $\mathrm{AF}$ guidelines $(1,78)$. There is no suggestion on the drug that can be used as the first choice in patients with unknown EF. Therefore, studies comparing the efficacy and side effects of treatment are needed to determine a standard treatment protocol for AF patients with RVR in the ED. Thus, our study aimed to compare the effectiveness and side effects of diltiazem or metoprolol treatment without knowing the EF in patients with AF with RVR in the ED.

\section{MATERIAL AND METHODS \\ Study Design and Setting}

The research study was planned as a retrospective cohort. Between January 1, 2018 and December 31, 2018, patients with AF with RVR admitted to a rural secondary care ED in Turkey were examined using the hospital data processing system and the ED records.

This study was approved by the non-interventional clinical researches ethics committee of Samsun Training and Research Hospital (09.12.2020, 2020/16/16). This ED treats 80,000 patients each year. Patients admitted with rhythm and rate problems had high priority and were followed up in the monitored area in the resuscitation room in the ED. Any medication or intervention administered to patients in the ED's monitored area is immediately noted on the patient follow-up form. Also, patients are in continuous ECG monitoring, and as a rule, their vital signs are recorded every half hour on the patient observation form. Emergency medicine specialists were working 24/7 in this rural ED.

\section{Selection of the Participants}

Patients aged 18 years and older, who were diagnosed with AF with RVR at the time of admission to the ED, were included in the study. Patients with a ventricular response $\geq 110 /$ min were selected as AF with RVR. The patients whose EF were not registered before the admission date and whose EF was measured after being consulted for cardiology following acute rate control were retrospectively and randomly selected.
The following exclusion criteria were applied: those whose data could not be accessed through the hospital data processing system and ED records or whose information was incomplete or pregnant patients. Patients with B-type natriuretic peptides (BNP) values $\geq 100 \mathrm{pg} / \mathrm{ml}$ and $\mathrm{N}$ terminal fragment brain natriuretic peptides (NT-ProBNP) $\geq 300 \mathrm{pg} / \mathrm{ml}$ were also excluded from the study, considering that they may have acute heart failure (9). Because the BNP and NT-Pro BNP values may not increase in obese patients, those patients' oxygen saturation levels were also examined. In the study conducted by Masip et al. (10), oxygen saturation <93\% for acute heart failure was accepted as the cut-off. Based on this, patients with oxygen saturation $<93 \%$ were not included in the present study. Moreover, patients presenting with unstable ventricular tachycardia, patients referred from another hospital, those with traumatic injuries, severely dehydrated patients, those with body temperature $>38^{\circ} \mathrm{C}$, those with an infectious disease, intoxicated patients, and those who received rate-control medications while in the ambulance, were excluded.

\section{Measurements and Outcomes}

The patients who first received $25 \mathrm{mg}$ intravenous (IV) diltiazem $(n=28)$ as a rate control drug were compared with those who first received $5 \mathrm{mg}$ IV metoprolol $(\mathrm{n}=22)$. A total of 50 patients eligible for the study were included. Age, gender, chronic diseases, heart rate and blood pressure at presentation, EF, previous history of AF, and drugs used were analyzed.

Thirty minutes after the first drug administration, the following data recorded for each patient were examined: heart rate, blood pressure, return to sinus rhythm after medical treatment, and the treatment administered as the second drug. The following factors were also analyzed: hospitalization status, need for intensive care, complications, such as hypotension or bradycardia after medical treatment, and re-admission to the ED within seven days.

\section{Statistical Analysis}

Statistical analyses were performed using the Jamovi software program (Version 1.2.22). Descriptive statistics of the categorical variables were presented as numbers and percentages. Descriptive statistics of the numerical variables were presented as mean \pm standard deviation or median (interquartile range) [minimum-maximum] depending on the distribution. Mann-Whitney $U$ test was used to compare two independent groups when the numerical variables did not show normal distribution. Pearson chi-square and Fisher's exact test were used in $2 \times 2$ tables to compare the differences between the categorical variables. Statistical significance level was accepted as 0.05 .

\section{RESULTS}

The mean age of the 50 patients included in the study was $71.4 \pm 12.3$ years, and $58 \%(n=29)$ were female. The mean systolic blood pressure at arrival in the ED was $124.30 \pm 26.30 \mathrm{~mm} / \mathrm{Hg}$, and the mean heart rate at arrival was $153.8 \pm 16.2 \mathrm{bpm}$. When the EF levels were examined, the levels were only reduced in $9(18 \%)$ patients. The presence of chronic diseases and the use of medications were also examined. It was found that $82 \%(n=41)$ of the patients had chronic diseases, as follows: hypertension (HT, 42\%, n=21), diabetes mellitus (DM, 26\%, $\mathrm{n}=13$ ), 
history of $\mathrm{AF}(42 \%, \mathrm{n}=21)$, coronary artery disease (CAD, $24 \%, \mathrm{n}=12$ ), and chronic obstructive pulmonary disease (COPD)-Asthma (18\%, $n=9)$. One patient $(2 \%)$ had a history of stroke. Likewise, $68 \%(n=34)$ of the patients were using drugs routinely; $38 \%(n=19)$ of these drugs were beta-blockers (BBs), 22\% $(n=11)$ were calcium channel blockers $(\mathrm{CCBs}), 6 \%(\mathrm{n}=3)$ were digoxin, and $2 \%$ $(\mathrm{n}=1)$ were amiodarone.

As the first drug treatment, diltiazem was given to $56 \%$ $(n=28)$ of the patients and metoprolol to $44 \%(n=22)$. The proportion of patients who needed a second drug infusion was $44 \%(n=22)$. For the second drug infusion, $13(59.1 \%)$ patients received metoprolol, two $(9.1 \%)$ received diltiazem, three $(13.6 \%)$ received digoxin, and four $(18.2 \%)$ received amiodarone. Ten $(20 \%)$ patients required hospitalization to the wards, and $3(6 \%)$ patients required intensive care. Hypotension developed in $5(10 \%)$ of the patients. Bradycardia was not observed in any of the patients. Five (10\%) of the patients revisited the ED within seven days with the diagnosis of AF-RVR.

According to the patients' EF, a statistically significant difference was found between the rates of the drugs used in the first administration. Accordingly, the proportion of patients that received diltiazem in those with preserved EF was significantly higher than those with reduced EF $(p=0.032)$. The proportion of patients that received metoprolol with reduced EF was significantly higher than those with preserved EF. However, no statistically significant difference was found between the rates of needing a second administration based on the EF of the patients ( $p=0.157$, Table 1$)$.

When considered separately according to EF, no statistically significant difference was found between the drugs used in the first administration and the need for the second administration (for preserved $E F \mathrm{p}=0.923$; for reduced $E F \mathrm{p}=0.999)$. However, in patients with preserved $\mathrm{EF}$, diltiazem was first administered to 26 patients, and a second administration was needed for $10(38.5 \%)$ patients. In patients with preserved EF, metoprolol was administered to 15 patients first, and a second medication was required for $6(40 \%)$ patients. In patients with reduced $\mathrm{EF}$, diltiazem was first administered to 2 patients, and a second medication was needed for 1 (50\%) patient. Metoprolol was first administered to 7 patients with reduced $\mathrm{EF}$, and a second drug treatment was necessary for $5(71.4 \%)$ patients (Table 2$)$.

There was no statistically significant difference between hospitalization rates $(p=0.665)$, the need for an intensive care unit $(\mathrm{p}=0.456)$, and the maximum heart rate change $(p=0.791)$ according to the patients' EF (Table 3 ).

The median heart rate change in 30 minutes was significantly higher in patients who received diltiazem at the first administration than patients treated with metoprolol $(\mathrm{p}=0.048)$. When other comparisons were examined, there was no statistically significant difference in the need for second infusion $(p=0.449)$, the occurrence of hypotension ( $\mathrm{p}=0.643)$, and the rates of return to sinus $(\mathrm{p}=0.462)$ based on the drugs given (Table 4$)$.

Table 5 demonstrates the difference between the need for second drug treatment and previous CCBs use, BBs use, or AF history. The proportion of patients with a history of AF who needed a second medication was significantly higher than those without an AF history $(\mathrm{p}=0.030)$.
Table 1. Distribution of diltiazem and metoprolol use and need for a second drug infusion according to EF, n (\%)

\begin{tabular}{lccc}
\hline & $\begin{array}{c}\text { Reduced } \\
(\mathbf{n = 9})\end{array}$ & $\begin{array}{c}\text { Preserved } \\
(\mathbf{n = 4 1 )}\end{array}$ & $\mathbf{p}$ \\
\hline First drug treatment & & & \\
$\quad$ Diltiazem & $2(22.2)$ & $26(63.4)$ & $\mathbf{0 . 0 3 2}$ \\
$\quad$ Metoprolol & $7(77.8)$ & $15(36.6)$ & \\
\hline Need for second drug infusion & $6(66.7)$ & $16(39.0)$ & 0.157 \\
\hline
\end{tabular}

EF: ejection fraction

Table 2. Examination of the second drug infusion need according to the first drug treatment used and the EF status

\begin{tabular}{lccc}
\hline EF: Preserved & $\begin{array}{c}\text { Diltiazem } \\
(\mathbf{n = 2 6})\end{array}$ & $\begin{array}{c}\text { Metoprolol } \\
(\mathbf{n = 1 5})\end{array}$ & $\mathbf{p}$ \\
\hline Need for second drug infusion & $10(38.5)$ & $6(40.0)$ & 0.923 \\
\hline \hline EF: Reduced & $\begin{array}{c}\text { Diltiazem } \\
(\mathbf{n = 2})\end{array}$ & $\begin{array}{c}\text { Metoprolol } \\
(\mathbf{n}=7)\end{array}$ & $\mathbf{p}$ \\
\hline Need for second drug infusion & $1(50.0)$ & $5(71.4)$ & 0.999 \\
\hline EF: ejection fraction & & &
\end{tabular}

Table 3. The distribution rate of hospitalization, intensive care need and maximum heart rate change according to EF, n (\%)

\begin{tabular}{lccc}
\hline & $\begin{array}{c}\text { Reduced } \\
(\mathbf{n = 9})\end{array}$ & $\begin{array}{c}\text { Preserved } \\
(\mathbf{n = 4 1 )}\end{array}$ & $\mathbf{p}$ \\
\hline Hospitalization & $1(11.1)$ & $9(22.0)$ & 0.665 \\
\hline Need for intensive care unit & $1(11.1)$ & $2(4.9)$ & 0.456 \\
\hline $\begin{array}{l}\text { Maximum heart rate change, } \\
\text { median (IQR) [min-max] }\end{array}$ & $\begin{array}{c}60(20) \\
{[32-99]}\end{array}$ & $\begin{array}{c}58(31) \\
{[8-110]}\end{array}$ & 0.791 \\
\hline EF:
\end{tabular}

EF: ejection fraction, IQR: interquartile range

Table 4. The distribution between the first drug treatment used and the need for the second drug infusion, change in heart rate at 30 minutes, hypotension, and return to sinus rhythm, n (\%)

\begin{tabular}{lccc}
\hline & $\begin{array}{c}\text { Diltiazem } \\
(\mathbf{n = 2 8})\end{array}$ & $\begin{array}{c}\text { Metoprolol } \\
(\mathbf{n = 2 2})\end{array}$ & $\mathbf{p}$ \\
\hline Heart rate change at 30 min, & $\begin{array}{c}48(42) \\
\text { median (IQR) [min-max] }\end{array}$ & $\begin{array}{c}28(33) \\
{[0-100]}\end{array}$ & 0.048 \\
\hline Need for second drug infusion & $11(39.3)$ & $11(50.0)$ & 0.449 \\
\hline Hypotension & $2(7.1)$ & $3(13.6)$ & 0.643 \\
\hline Return to sinus & $9(32.1)$ & $5(22.7)$ & 0.462 \\
\hline IQR: interquartile range & & &
\end{tabular}

IQR: interquartile range

Table 5. The distribution between the need for second drug infusion and previous calcium channel blocker use, beta-blocker use, and AF history, n (\%)

\begin{tabular}{lccc}
\hline Calcium Channel Blocker & Yes $(\mathbf{n}=11)$ & No $(\mathbf{n}=39)$ & $\mathbf{p}$ \\
\hline Need for second drug infusion & $4(36.4)$ & $18(46.2)$ & 0.734 \\
\hline \hline Beta-Blocker & Yes $(\mathbf{n = 1 9})$ & No $(\mathbf{n = 3 1})$ & $\mathbf{p}$ \\
\hline Need for second drug infusion & $10(52.6)$ & $12(38.7)$ & 0.336 \\
\hline \hline AF History & Yes $(\mathbf{n = 2 1})$ & No $(\mathbf{n = 2 9})$ & $\mathbf{p}$ \\
\hline Need for second drug infusion & $13(61.9)$ & $9(31.0)$ & $\mathbf{0 . 0 3 0}$ \\
\hline AF: atrial fibrillation & & &
\end{tabular}




\section{DISCUSSION}

Diltiazem and metoprolol are the drugs most often used to treat AF with RVR in ED. The purpose of this study was to compare the efficacy and side effects of emergency medicine physicians' treatments in patients with $\mathrm{AF}$ with RVR with unknown EF. This research is also a call for preparing a standard treatment protocol to be used safely in AF patients with RVR with unknown EF for supporting the physicians working in rural EDs where cardiologists are unavailable.

Current guidelines for rate control of AF recommend using diltiazem or metoprolol, taking into account the patient's EF, decompensation, and hypotension status $(1,7,8)$. Although physicians working in the ED can recognize the patient's decompensation and hypotension state alone, it may be difficult for them to predict the patient's EF. Experts reported that more than one-third of patients diagnosed with heart failure by primary care physicians without echocardiography was inaccurate according to the European Society of Cardiology (ESC) guidelines (11). In our study, diltiazem was found to decrease the patients' heart rate more effectively at 30 minutes than metoprolol, but there was no significant difference in the need for a second drug. No significant difference was observed between diltiazem and metoprolol in terms of side effects. In the study of Hines et al. (12), there was no significant difference between the groups in the frequency of hypotension. Demircan et al. (13), showed that diltiazem and metoprolol were similar in efficacy and side effects in patients, regardless of EF; diltiazem also decreased the heart rate more quickly than metoprolol, and the reduction was greater at different time intervals. In support of this study, Memiş et al. (14), showed that diltiazem was more effective in RVR and the EF value was the determining factor for maintaining rate control. Martindale et al. (15), showed that diltiazem provides more effective rate control than metoprolol.

Heart rate control is an essential part of treatment in patients with AF. The target heart rate is still uncertain in $\mathrm{AF}$ rate control. AF acute rate control treatment recommendations in the 2020 ESC AF guideline are based on the patient's EF status (1). It is recommended to have a target heart rate $<80 \mathrm{bpm}$ during resting and a target heart rate $<110 \mathrm{bpm}$ during moderate exercise. In AF, BBs, $\mathrm{CCBs}$, and in specific cases, digoxin and amiodarone, are the agents that can be used for acute heart rate control. According to the 2020 ESC AF guideline, in patients with an $\mathrm{EF} \geq$ of $40 \%$, metoprolol, diltiazem, or verapamil are the drugs of the first choice for acute heart rate control. $\mathrm{BBs}$ or digoxin use is recommended for patients with $\mathrm{EF}$ $<40 \%$ (1). Although heart failure preserved EF patients accounted for more than half of patients with heart failure, randomized controlled trials comparing $\mathrm{BBs}$ to placebo are few (16). A meta-analysis published in 2014 stated that BBs should not be used as standard therapy in patients with heart failure with reduced EF plus AF (17).

The 2020 Canadian Cardiovascular Society / Canadian Heart Rhythm Society comprehensive guidelines have taken into account the patient's EF status in drugs to be used to control heart rate in AF. Unless contraindicated, $\mathrm{BBs}$ or $\mathrm{CCBs}$ in case of $\mathrm{EF} \geq 40 \%$, and $\mathrm{BBs}$ if $\mathrm{EF}<40 \%$ are recommended as the first choice. It also reported that metoprolol might be preferred in patients with AF with acute coronary syndrome who need rate control (7).
The American Heart Association (AHA) / American College of Cardiology (ACC) / Heart Rhythm Society (HRS) guideline recommends which agent to choose in AF rate control, paying attention to whether there is heart failure or not. The use of nondihydropyridine $\mathrm{CCBs}$ or $\mathrm{BBs}$ for acute rate control of $\mathrm{AF}$ patients without heart failure is suggested as a class-1 recommendation in the guideline. It reported that $\mathrm{BBs}$ are the most commonly used agent in acute rate control. It also emphasized that BBs' use should be avoided, especially in decompensated heart failure or acute COPD attack (8).

Atzema et al. (18), showed that the choice of drug used in RVR rate control changes depending on the size of EDs and the presence of a teaching hospital, but overall, CCBs were used more than BBs. Our investigation revealed that emergency medicine specialists tend to use diltiazem more often than other drugs.

According to the patients' EF, we found a statistically significant difference between the rates of the drugs used in the first drug treatment. The proportion of the patients with preserved $\mathrm{EF}$ that received diltiazem was significantly higher than those with reduced EF. On the other hand, the proportion of patients with reduced EF who received metoprolol was significantly higher than those with preserved EF.

No statistically significant difference was found between needing a second administration based on the patients' EF. Moreover, no statistically significant difference was observed between hospitalization rates and the need for an intensive care unit according to $\mathrm{EF}$ and the median maximum heart rate change.

It was observed that emergency medicine physicians tend to use diltiazem independently from EF. Studies can be conducted to determine why they use diltiazem. Regular training should be provided to ensure that their knowledge is up to date.

Demircan et al. (13), reported no significant difference in hypotension between patients using diltiazem and metoprolol. In our study, hypotension was observed in patients using diltiazem and metoprolol, but no statistically significant difference was observed between the groups.

As explained what to do in patients with ST-segment elevation myocardial infarction in a center without primary percutaneous intervention capacity; it should not be neglected to include additional recommendations in the guidelines for the drug treatment to be selected for rate control of AF patients with RVR in centers where EF measurement cannot be performed. For this purpose, disseminating echocardiography in emergency services and providing emergency physicians with basic eco skills may also contribute to the solution.

Most of the patients with AF in the ED investigated in this study could not be included in the data because we conducted the study in patients with unknown EF. Another limitation of the study was that it was a retrospective design. There is a need for randomized, controlled, prospective studies involving more patients.

\section{CONCLUSION}

There is a lack of information in the guidelines on how emergency physicians, especially in rural hospitals, should achieve acute rate control in AF patients with RVR with 
unknown EF. We observed that emergency medicine physicians tend to use diltiazem for heart rate control more than metoprolol. We concluded that patients treated with diltiazem had a heart rate decrease more quickly than those treated with metoprolol. Furthermore, patients with a history of AF needed to be administered a second drug infusion for heart rate control.

Ethics Committee Approval: The study was approved by the Ethics Committee of Samsun Training and Research Hospital (09.12.2020, 2020/16/16).

Conflict of Interest: None declared by the authors.

Financial Disclosure: None declared by the authors.

Acknowledgements: None declared by the authors.

Author Contributions: Idea/Concept: MCD, MD, EP; Design: MCD, MD, EP; Data Collection/Processing: MCD, MD, EP; Analysis/Interpretation: MCD, MD, EP; Literature Review: MCD, EP, GA; Drafting/Writing: MCD, MD, EP, GA; Critical Review: MCD, EP.

\section{REFERENCES}

1. Hindricks G, Potpara T, Dagres N, Arbelo E, Bax JJ, Blomström-Lundqvist C, et al. 2020 ESC Guidelines for the diagnosis and management of atrial fibrillation developed in collaboration with the European Association of Cardio-Thoracic Surgery (EACTS). Eur Heart J. 2021;42(5):373-498.

2. Benjamin EJ, Muntner P, Alonso A, Bittencourt MS, Callaway CW, Carson AP, et al. Heart disease and stroke statistics-2019 update: A report from the American Heart Association. Circulation. 2019;139(10):e56-e528.

3. Chugh SS, Havmoeller R, Narayanan K, Singh D, Rienstra M, Benjamin EJ, et al. Worldwide epidemiology of atrial fibrillation: a Global Burden of Disease 2010 Study. Circulation. 2014;129(8):837-47.

4. Vandermolen JL, Sadaf MI, Gehi AK. Management and disposition of atrial fibrillation in the emergency department: A systematic review. J Atr Fibrillation. 2018;11(1):1810.

5. Al-Khatib SM, Allen LaPointe NM, Chatterjee R, Crowley MJ, Dupre ME, Kong DF, et al. Rate-and rhythm-control therapies in patients with atrial fibrillation: a systematic review. Ann Intern Med. 2014;160(11):760-73.

6. Wyse DG, Waldo AL, DiMarco JP, Domanski MJ, Rosenberg Y, Schron EB, et al. A comparison of rate control and rhythm control in patients with atrial fibrillation. N Engl J Med. 2002;347(23):1825-33.

7. Andrade JG, Aguilar M, Atzema C, Bell A, Cairns JA, Cheung CC, et al. The 2020 Canadian Cardiovascular Society/Canadian Heart Rhythm Society comprehensive guidelines for the management of atrial fibrillation. Can J Cardiol. 2020;36(12):1847-948.
8. January CT, Wann LS, Alpert JS, Calkins H, Cigarroa JE, Cleveland JC Jr, et al. 2014 AHA/ACC/HRS guideline for the management of patients with atrial fibrillation: a report of the American College of Cardiology/American Heart Association Task Force on Practice Guidelines and the Heart Rhythm Society. J Am Coll Cardiol. 2014;64(21):e1-76.

9. Ponikowski P, Voors AA, Anker SD, Bueno H, Cleland JGF, Coats AJS, et al. 2016 ESC Guidelines for the diagnosis and treatment of acute and chronic heart failure: The Task Force for the diagnosis and treatment of acute and chronic heart failure of the European Society of Cardiology (ESC) Developed with the special contribution of the Heart Failure Association (HFA) of the ESC. Eur Heart J. 2016;37(27):2129-2200.

10. Masip J, Gayà M, Páez J, Betbesé A, Vecilla F, Manresa R, et al. Pulse oximetry in the diagnosis of acute heart failure. Rev Esp Cardiol (Engl Ed). 2012;65(10):879-84.

11. Valk MJ, Mosterd A, Broekhuizen BD, Zuithoff NP, Landman MA, Hoes AW, et al. Overdiagnosis of heart failure in primary care: a cross-sectional study. $\mathrm{Br} \mathrm{J}$ Gen Pract. 2016;66(649):e587-92.

12. Hines MC, Reed BN, Ivaturi V, Bontempo LJ, Bond $\mathrm{MC}$, Hayes BD. Diltiazem versus metoprolol for rate control in atrial fibrillation with rapid ventricular response in the emergency department. Am J Health Syst Pharm. 2016;73(24):2068-76.

13. Demircan C, Cikriklar HI, Engindeniz Z, Cebicci H, Atar N, Guler V, et al. Comparison of the effectiveness of intravenous diltiazem and metoprolol in the management of rapid ventricular rate in atrial fibrillation. Emerg Med J. 2005;22(6):411-4.

14. Memiş MB, Rohat A, Öztürk TC, Özge O, Özgür O. Which one is the first choice for rapid ventricular rate atrial fibrillation in emergency department: Metoprolol or Diltiazem? A randomized clinical trial. J Surg Med. 2019;3(1):13-7.

15. Martindale JL, deSouza IS, Silverberg M, Freedman J, Sinert R. $\beta$-Blockers versus calcium channel blockers for acute rate control of atrial fibrillation with rapid ventricular response: a systematic review. Eur J Emerg Med. 2015;22(3):150-4.

16. Liu F, Chen Y, Feng X, Teng Z, Yuan Y, Bin J. Effects of beta-blockers on heart failure with preserved ejection fraction: a meta-analysis. PloS One. 2014;9(3):e90555.

17. Kotecha D, Holmes J, Krum H, Altman DG, Manzano L, Cleland JG, et al. Efficacy of $\beta$ blockers in patients with heart failure plus atrial fibrillation: an individualpatient data meta-analysis. Lancet. 2014;384(9961):2235-43.

18. Atzema CL, Austin PC. Rate control with betablockers versus calcium channel blockers in the emergency setting: Predictors of medication class choice and associated hospitalization. Acad Emerg Med. 2017;24(11):1334-48. 